\title{
Hormonal regulation and differential expression of neuropilin (NRP)-1 and NRP-2 genes in bovine granulosa cells
}

\author{
Takashi Shimizu ${ }^{1}$, Barana C Jayawardana ${ }^{1}$, Hiromi Nishimoto ${ }^{2}$, Etsushi Kaneko ${ }^{1}$, \\ Masafumi Tetsuka ${ }^{2}$ and Akio Miyamoto ${ }^{1}$ \\ ${ }^{1}$ Graduate School of Animal and Food Hygiene and ${ }^{2}$ Department of Agriculture and Life Science, Obihiro \\ University of Agriculture and Veterinary Medicine, Inada-Machi, Obihiro, Hokkaido, 080-8555 Japan
}

Correspondence should be addressed to T Shimizu; Email: shimizut@obihiro.ac.jp

\begin{abstract}
Although much is known about the biology of vascular endothelial growth factor (VEGF) and its receptors, little is known about the role of the VEGF receptors neuropilin (NRP)-1 and NRP-2 in the process of bovine follicle development. The aim of the present study was to examine the hormonal regulation of NRP-1 and NRP-2 mRNAs by real-time PCR in follicles from the bovine ovary and in cultured granulosa cells. The NRP-1 gene was expressed in the granulosa and theca cells in the post-selection (POF) and pre-selection (PRF) follicles in the bovine ovary. In contrast, the NRP-2 gene was expressed only in the theca cells in the POF and the PRF. The level of NRP-1 mRNA was significantly increased by treatment of the cultured granulosa cells with $10 \mathrm{ng} / \mathrm{ml}$ estradiol (E2). In contrast, the addition of progesterone (P4) to the culture medium decreased the expression of the NRP-1 gene. The level of NRP-1 mRNA was increased by $10 \mathrm{ng} / \mathrm{ml}$ E2 with or without $1 \mathrm{ng} / \mathrm{ml} \mathrm{P4,} \mathrm{but} \mathrm{the}$ level of NRP-1 mRNA was decreased if the P4 level was increased to $10 \mathrm{ng} / \mathrm{ml}$, even when $1 \mathrm{ng} / \mathrm{ml}$ E2 was also added. Folliclestimulating hormone did not stimulate the expression of the NRP-1 gene. These results are the first data showing that NRP-1, but not NRP-2, is expressed in the granulosa cells of bovine follicles and that NRP-1 gene expression is regulated by sex steroids. Our findings suggest the involvement of NRP-1 in follicle development in the cow.

Reproduction (2006) 131 555-559
\end{abstract}

\section{Introduction}

The impact of vascular endothelial growth factor (VEGF) as a central regulator of angiogenesis in the ovary was demonstrated in studies using the techniques of gene or protein injection (Hazzard et al. 2002, Shimizu et al. 2003, Xu et al. 2005). VEGF induces signal transduction in the cells via VEGF receptors that belong to the tyrosine-kinase receptor family. The fms-like-tyrosine kinase-1 (Flt-1) and fetal liver kinase-1 (Flk-1) bind to VEGF with high affinity. The Flt-1 (or VEGFR-1) and Flk-1 (or VEGFR-2) genes are expressed in the granulosa (Berisha et al. 2000) and theca (Shimizu et al. 2002) cells of follicles in many species in association with the activation of granulosa cell function and the process of follicle growth in the ovary.

The affinity purification approach revealed that the VEGF receptors in breast cancer MDA-MB-231 cells are encoded by neuropilin-1 (NRP-1) (Soker et al. 1998). In addition, the expression cloning approach led to the identification of another receptor for VEGF165, which turned out to be the product of the closely related gene, neuropilin-2 (NRP-2) (He \& Tessier-Lavigne 1997, Soker et al. 1998). The neuropilins have a short intracellular domain and are therefore unlikely to function as independent receptors. Indeed, no response to VEGF165 was observed when cells expressing NRP-1 but no other VEGF receptors were stimulated with VEGF165 (Soker et al. 1998). It is thus likely that NRP-1 is a VEGF165 coreceptor. This assumption is supported by studies showing that VEGFR-2 binds to VEGF165 more efficiently in cells expressing NRP-1, and that this potentiating effect is subsequently translated into a better migratory response to VEGF165 as compared with the migratory response of cells expressing VEGFR-2 but not NRP-1 (Soker et al. 1998).

NRP-1 and NRP-2 are expressed in the ovaries of cyclic (Pavelock et al. 2001) and immature (Miyabayashi et al. 2005) rats. These reports suggest the possibility that NRP-1 and NRP-2 take part in vascular formation in a manner dependent on follicular development. However, whether NRP-1 and NRP-2 are expressed in the granulosa or theca cells in the ovary is still unknown. In addition, it is still not known whether the expression of these factors is influenced by steroid hormones and follicle-stimulating hormone $(\mathrm{FSH})$. Thus, we examined the expression of NRP-1 and NRP-2 in the granulosa and theca cells of 
post-selection and pre-selection follicles in the bovine ovary and the effect of steroid hormones and FSH on the expression of these genes in cultured bovine granulosa cells.

\section{Materials and Methods}

\section{Sample collection}

Paired ovaries were obtained from 21- to 26-month-old nonparous Holstein $\times$ Japanese Black F1 cattle at a local slaughterhouse. Only ovarian pairs with a corpus luteum and apparently normal follicles were used in the present study. Follicular fluid (FF) was aspirated from selected follicles using a syringe fitted with a 20 gauge needle and stored at $-20^{\circ} \mathrm{C}$. Theca cell layer and granulosa cells were harvested from aspirated follicles. The tissue samples were placed in the RNAlater (Ambion, Austin, TX, USA) and frozen at $-30^{\circ} \mathrm{C}$. Follicles were classified into two groups based on the diameter: post-selection follicles (POF) $>8.5 \mathrm{~mm}$ in diameter; pre-selection follicles (PRF) $7.0-8.5 \mathrm{~mm}$ in diameter.

\section{Isolation and culture of bovine granulosa cells}

Ovaries were obtained at a nearby slaughterhouse from cows and heifers just after slaughter. After transport to the laboratory at $30^{\circ} \mathrm{C}$, the ovaries were washed three times with prewarmed McCoy $5 \mathrm{~A}$ medium. Granulosa cells were collected from medium sized follicles $(4-7 \mathrm{~mm})$ by aspiration using a needle (18 gauge) and syringe (plastic, $10 \mathrm{ml}$ ) and washed in Dulbecco's modified Eagle's/F12 (DMEM/F12) medium. Then, the cell suspension was centrifuged, resuspended, and seeded at a density of 2 - to $5 \times 10^{5}$ cells per well (24-well culture plates) in $1 \mathrm{ml}$ DMEM/F12 containing $10 \%$ fetal calf serum (FCS) and antibiotics. The cells were cultured for $24 \mathrm{~h}$ at $37^{\circ} \mathrm{C}$ in a $5 \% \mathrm{CO}_{2}$ atmosphere and then the wells were washed with DMEM/F12 to remove unattached cells and remaining tissue debris. The culture medium was replaced with serum-free medium supplemented with estradiol-17 $\beta$ $(\mathrm{E} 2,1-100 \mathrm{ng} / \mathrm{ml})$, progesterone $(\mathrm{P} 4,1-100 \mathrm{ng} / \mathrm{ml})$ and FSH $(1-10 \mathrm{ng} / \mathrm{ml})$ at several concentrations and the culture was continued for $6 \mathrm{~h}$. Treatments were terminated by aspirating the medium and rinsing the cells two times with phosphatebuffered saline, and the cells were used for RNA extraction.

\section{RNA extraction, reverse transcription $(R T)$ and quantitative PCR}

Tissue samples were homogenized in denaturing solution containing $4 \mathrm{M}$ guanidium thiocyanate (Wako Pure Chemical Industries, Ltd, Osaka, Japan), $25 \mathrm{mM}$ sodium citrate (Wako), 0.5\% sarkosyl (Sigma Chemical Co., St Louis, MO, USA) and 0.1 M $\beta$-mercapto ethanol (Kanto Chemical Co. Inc., Tokyo Japan). Total RNA was extracted with phenol-chloroform, further purified, and treated with DNase using a commercial kit (SV Total RNA Isolation System; Promega Co., Madison, WI, USA), and then frozen at $-20^{\circ} \mathrm{C}$ in RNA Storage Solution (Ambion). Singlestrand cDNA was reverse transcribed from total RNA $(0.5 \mu \mathrm{g}-5 \mu \mathrm{g})$ using a 1 st Strand cDNA Synthesis Kit for RT-PCR (Roche Diagnostics Co., Indianapolis, IN, USA) and random primer. The RT conditions consisted of $10 \mathrm{~min}$ annealing at $25^{\circ} \mathrm{C}, 60 \mathrm{~min}$ CDNA synthesis at $42^{\circ} \mathrm{C}$, and $5 \mathrm{~min}$ inactivation at $99^{\circ} \mathrm{C}$.

Genes for NRP-1, NRP-2 and $\beta$-actin were quantified by real-time PCR with LightCycler (Roche Diagnostics Co.) using a commercial kit (QuantiTect SYBR Green PCR; QIAGEN GmbH, Hilden, Germany). PCR was performed with the following primers: NRP-1 (GenBank accession no. AF395335), 5'-CCA GAA GCC AGA GGA GTA CG-3', 5'-CTT TTC CGA TTT CAC CCT CA-3'; NRP-2 (GenBank accession no. AF 534636), 5'-TTC AGT GCA ATG TCC CTC TG-3', 5'-AGT CCA AGT TGG GTG TCC AG-3' and $\beta$-actin, $5^{\prime}$-CCA AGG CCA ACC GTG AGA AGA T $-3^{\prime}, 5^{\prime}$ CAA CGT TCC GTG AGG ATC TTC A - $3^{\prime}$. The PCR conditions were $2 \mathrm{~min}$ at $95^{\circ} \mathrm{C}$, followed by 40 cycles of $30 \mathrm{~s}$ at $95^{\circ} \mathrm{C}, 30 \mathrm{~s}$ at $58^{\circ} \mathrm{C}$, and $45 \mathrm{~s}$ at $72^{\circ} \mathrm{C}$. The amounts of the product at each step were monitored in real time.

\section{Steroid hormone extraction and assay}

Concentrations of E2 in the FF and culture medium, and P4 in the FF samples were estimated using an enzyme immunoassay (EIA) as described previously (Miyamoto et al. 1992, Wijayagunawardane et al. 1998). Steroid hormones were extracted with diethyl ether. The extraction efficiency was $85 \%$. The ranges of the standard curves were $2-2000 \mathrm{pg} / \mathrm{ml}$ for E2 and $0.05-50 \mathrm{ng} / \mathrm{ml}$ for P4. The intra- and interassay coefficients of variation were 6.2 and $8.5 \%$ for $\mathrm{E} 2,4.5$ and $7.4 \%$ for $\mathrm{P} 4$.

Table 1 Mean follicle diameter, and concentrations of estradiol (E) and progesterone (P) in follicular fluid, and E/P ratio in cattle. Values are means \pm S.E.M.

\begin{tabular}{lcccc}
\hline & & \multicolumn{2}{c}{ Follicular fluid } \\
\cline { 3 - 4 } Follicle & Mean follicle diameter $(\mathrm{mm})$ & Estradiol $(\mathrm{ng} / \mathrm{ml})$ & Progesterone $(\mathrm{ng} / \mathrm{ml})$ & E/P ratio \\
\hline Post-selection follicle $(n=4)$ & $15.6 \pm 1.6$ & $57.6 \pm 13.4$ & $18.7 \pm 2.5$ & $3.3 \pm 1.1$ \\
Pre-selection follicle $(n=5)$ & $7.6 \pm 0.2$ & $4.08 \pm 1.5^{*}$ & $8.2 \pm 1.4^{*}$ & $0.54 \pm 0.2^{*}$ \\
\hline
\end{tabular}

$* P<0.05$ versus post-selection follicle. 


\section{Data analysis}

All data are presented as means \pm S.E.M. Differences in the expression of NRP-1 and NRP-2 between the POF and PRF were analyzed by Student's $t$-test. Values of NRP-1 and NRP-2 in treated bovine granulosa cells were tested for significant differences using ANOVA, followed by the Fisher's Least Significant Difference test as a multiple comparison test. Differences were considered significant at $P<0.05$ or less.

\section{Results}

\section{Follicle characteristics}

Table 1 shows the characteristics of the ovarian follicles used in this study. The concentrations of estradiol and progesterone in follicular fluid were significantly higher in the POF than in the PRF. The ratios of E/P in the POF and PRF were $3.3 \pm 1.1$ and $0.54 \pm 0.2$ respectively.

\section{Expression of NRP-1 and NRP-2 mRNA in granulosa and theca cells of POF and PRF}

The NRP-1 gene was expressed in the granulosa and theca cells in the POF and the PRF in the bovine ovary (Fig. 1A). In contrast, the NRP-2 gene was only expressed in the theca cells in the POF and the PRF (Fig. 1A). The level of NRP-1 mRNA was significantly higher in the granulosa cells of the POF than in those of the PRF (Fig. 1B). The expression of the NRP-1 and NRP-2 mRNAs in the theca cells showed no significant change between the POF and the PRF (Fig. 1C and 1D).

\section{Effect of estradiol or progesterone on the NRP-1 gene}

The level of NRP-1 mRNA in the cultured granulosa cells significantly increased when the cells were treated with $10 \mathrm{ng} / \mathrm{ml}$ estradiol (Fig. 2A). In contrast, the addition of progesterone to the culture medium decreased the expression of the NRP-1 gene (Fig. 2B). The level of NRP-1 mRNA in cells treated with $10 \mathrm{ng} / \mathrm{ml}$ estradiol plus $1 \mathrm{ng} / \mathrm{ml}$ progesterone was the same as that in cells treated with estradiol alone and was significantly increased as compared with the control level (Fig. 2C). In cells treated with $1 \mathrm{ng} / \mathrm{ml}$ estradiol plus $10 \mathrm{ng} / \mathrm{ml}$ progesterone, the level of NRP-1 mRNA expression did not differ from that in cells treated with $10 \mathrm{ng} / \mathrm{ml}$ progesterone alone (Fig. 2D).

\section{Effect of combination of estradiol and FSH on the NRP-1 gene}

The expression of the NRP-1 gene in the granulosa cells was not stimulated by FSH (Fig. 3A). Analysis of estradiol production by granulosa cells cultured in serum-free medium showed that FSH did not stimulate estradiol secretion $(223 \pm 52, \quad 197 \pm 24, \quad 269 \pm 78$ and $254 \pm 34 \mathrm{pg} / \mathrm{ml}$
A
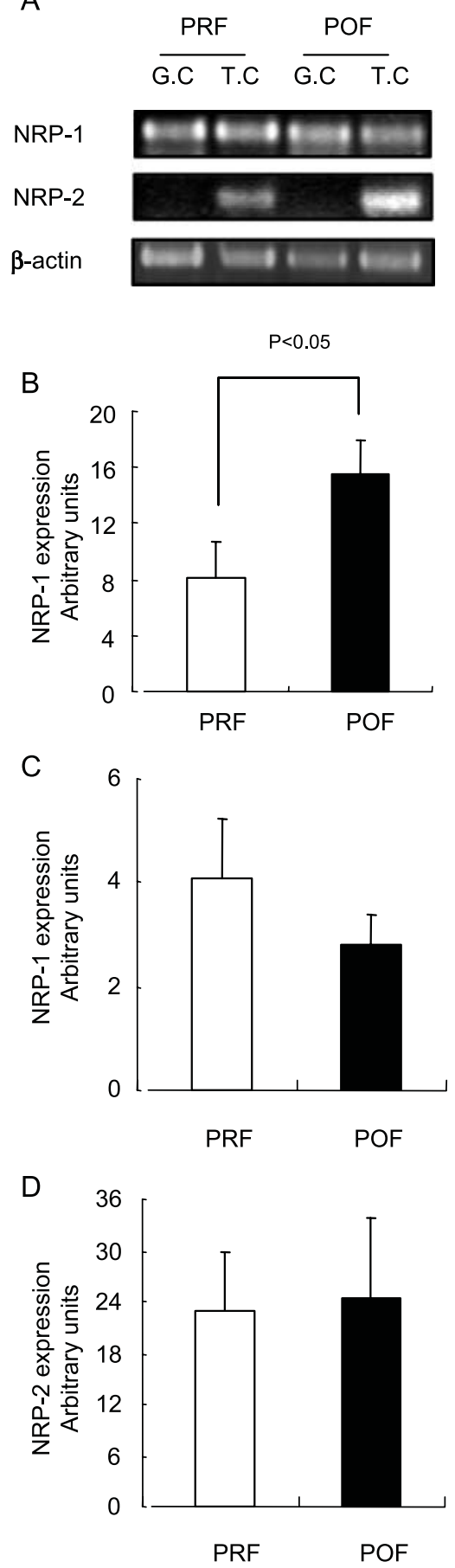

Figure 1 (A) Expression of NRP-1 and NRP-2 genes in granulosa (G.C.) and theca cells (T.C.) and (B-D) levels of NRP-1 and NRP-2 mRNA in the granulosa (B) and theca (C and D) cells of post-selection (POF) $(n=4)$ and pre-selection (PRF) $(n=5)$ follicles in the bovine ovary. The mRNA levels were analyzed by a quantitative RT-PCR. The data are expressed as means \pm S.E.M. $\beta$-Actin was used as a loading control.

for $0,1,5,10 \mathrm{ng} / \mathrm{ml} \mathrm{FSH}$ respectively). In cells treated with a constant concentration of $1 \mathrm{ng} / \mathrm{ml}$ estradiol, the expression of NRP-1 was not induced even if the FSH concentration in the medium was increased (Fig. 3B). 

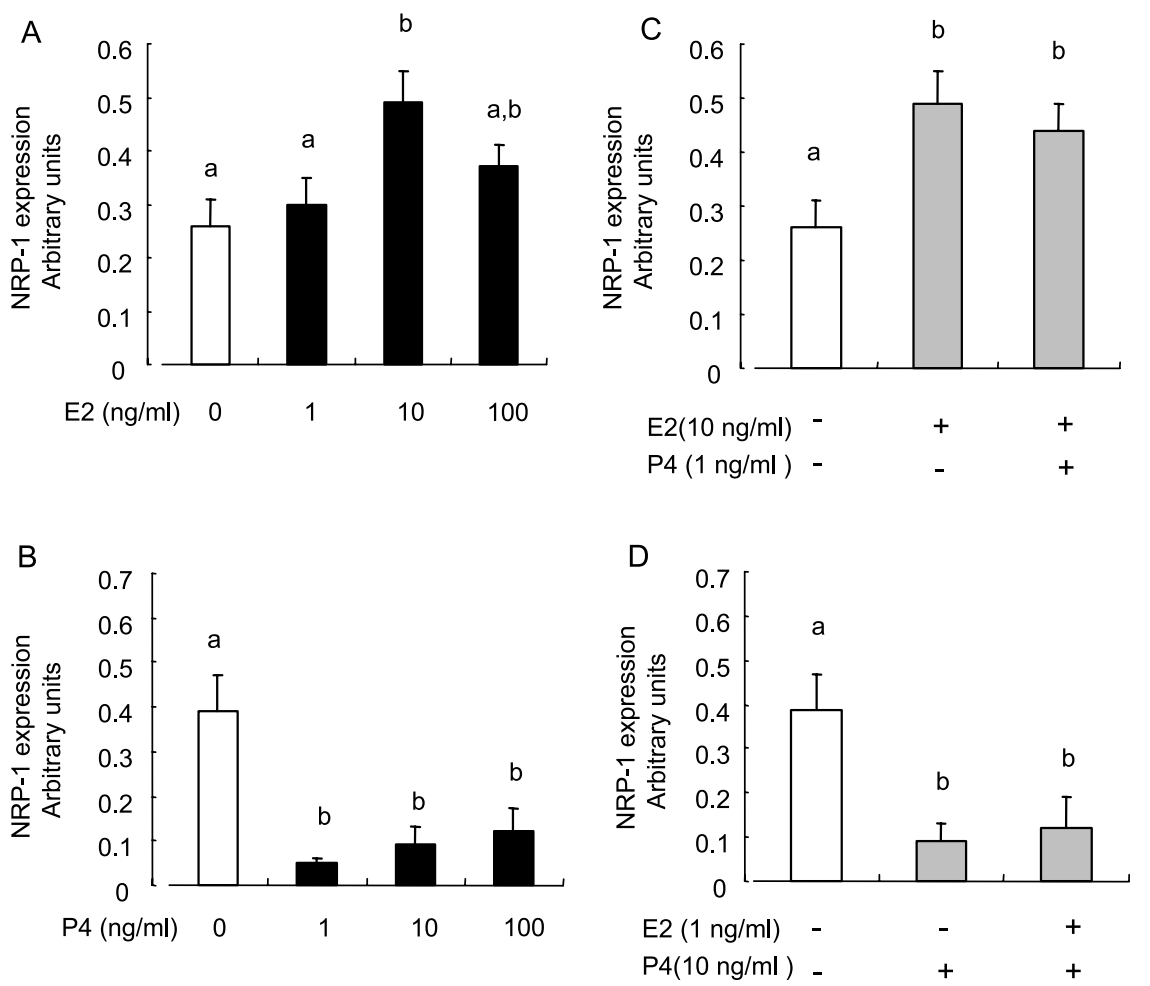

Figure 2 NRP-1 mRNA expression in cultured bovine granulosa cells is differentially regulated by estradiol and progesterone. The indicated concentration of estradiol (E2) or progesterone $(\mathrm{P} 4)$ was added to the culture medium. The mRNA levels were analyzed by a quantitative RT-PCR. The data are expressed as means \pm S.E.M. of results obtained in three experiments. Different superscripts denote significantly different values $(P<0.05)$.

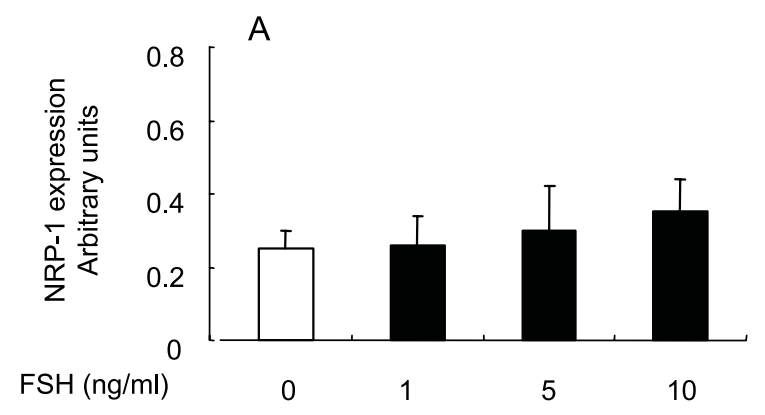

\section{Discussion}

The present study provides the first evidence that NRP-1, but not NRP-2, is expressed in the granulosa cells of the antral follicle from the bovine ovary, and that the expression of the NRP-1 gene in cultured bovine granulosa cells is enhanced by estradiol and reduced by progesterone. Previous studies showed that NRP-1 and NRP-2 are expressed in the cyclic rat uterus (Pavelock et al. 2001) and immature rat ovary (Miyabayashi et al. 2005). Our data using the bovine ovary demonstrated that the NRP-1 gene is expressed in granulosa and theca cells, while the NRP-2 gene is only expressed in the theca cells. This result suggests that the functions may differ between NRP-1 and NRP-2 in the bovine ovary during the course of follicle development.

We found that the expression of the NRP- 1 gene significantly increased when cultured granulosa cells were treated with $10 \mathrm{ng} / \mathrm{ml}$ estradiol. Estradiol is one of the major factors in follicle selection, which is a critical phenomenon in monovular species such as cattle (Ginther et al. 2001). Co-expression of NRP-1 and Flk-1 (or VEGFR2) in porcine aortic endothelial cells was reported to enhance VEGF165 binding to Flk-1 and the Flk-1-meditated chemotactic activity of VEGF165, suggesting that NRP-1 is a coreceptor for Flk-1 (Soker et al. 1998). VEGF and Flk-1/KDR mRNA and protein were both detectable in follicle tissue sections and in in vitro cultured granulosa cells (Greenaway et al. 2004). Moreover, the VEGF gene is highly expressed in the granulosa cells of large follicles (dominant) that possess high concentrations of estradiol (Berisha et al. 2000). Therefore, our data suggest that estradiol-stimulated NRP-1 is not regulated by follicle-stimulating hormone $(\mathrm{FSH})$. The indicated concentration of FSH with or without estradiol (E2) was added to the culture medium. The mRNA levels were analyzed by a quantitative RT-PCR. The data are expressed as means \pm S.E.M. of results obtained in three experiments. 
expression may be involved in the final growth of the preovulatory (dominant) follicle. On the other hand, the present study demonstrated that $\mathrm{P} 4$ reduced the expression of the NRP-1 gene in granulosa cells, suggesting that the expression of NRP-1 gene may be inhibited via the progesterone receptor. However, the mechanism of the regulation of NRP-1 expression by progesterone is currently unknown. Our data basically indicate that estradiol is stimulative and progesterone is suppressive towards NRP-1 expression in bovine granulosa cells.

We also observed that the expression of the NRP-1 gene in bovine granulosa cells was not stimulated by FSH alone. In addition, NRP-1 gene expression was not changed even if a low concentration of estradiol was added to FSH. In general, the expression of various factors such as growth factors is stimulated by the combination of FSH and estradiol (Voge et al. 2004). Our data suggest that, in the presence of $\mathrm{FSH}$, estradiol might not affect the expression of the NRP-1 gene in bovine granulosa cells.

In summary, we have shown for the first time the differential expression and hormonal regulation of neuropilins in the bovine ovary. Notably, steroid hormone regulation of the NRP-1 gene in the granulosa cells may be associated with follicular angiogenesis during follicle development. Consequently, additional studies will be needed to examine the detailed expression pathway of the NRP-1 gene during follicle development in the bovine ovary.

\section{Acknowledgements}

The authors thank Dr K Okuda, Okayama University Japan, for progesterone antibody. This study was supported by the 21st Century COE program (A-1), Ministry of Education, Culture, Science and Technology, Japan, a Grant-in-Aid for Scientific Research of the Japan Society for the Promotion of Science (JSPS) and the Akiyama Foundation, Japan. E K is a postdoctoral fellow supported by the COE program. The authors declare that there is no conflict of interest that would prejudice the impartiality of this scientific work.

\section{References}

Berisha B, Schams D, Kosmann M, Amselgruber W \& Einspanier R 2000 Expression and localisation of vascular endothelial growth factor and basic fibroblast growth factor during the final growth of bovine ovarian follicles. Journal of Endocrinology 167 371-382.

Ginther OJ, Beg MA, Bergfelt DR, Donadeu FX \& Kot K 2001 Follicle selection in monovular species. Biology of Reproduction $\mathbf{6 5}$ 638-647.
Greenaway J, Connor K, Pedersen HG, Coomber BL, LaMarre J \& Petrik J 2004 Vascular endothelial growth factor and its receptor, Flk-1/KDR, are cytoprotective in the extravascular compartment of the ovarian follicle. Endocrinology 145 2896-2905.

Hazzard TM, Rohan RM, Molskness TA, Fanton JW, D'Amato RJ \& Stouffer RL 2002 Injection of antiangiogenic agents into the macaque preovulatory follicle: disruption of corpus luteum development and function. Endocrine 17 199-206.

He Z \& Tessier-Lavigne $\mathbf{M} 1997$ Neuropilin is a receptor for the axonal chemorepellent semaphorin III. Cell 90 739-751.

Miyabayashi K, Shimizu T, Kawauchi C, Sasada H \& Sato E 2005 Changes of mRNA expression of vascular endothelial growth factor (VEGF), angiopoietins and their specific receptors during the periovulatory phase in eCG/hCG-primed immature female rats. Journal of Experimental Zoology Part A 303 590-597.

Miyamoto A, Okuda K, Schweigert FJ \& Schams D 1992 Effects of basic fibroblast growth factor, transforming growth factor-beta and nerve growth factor on the secretory function of the bovine corpus luteum in vitro. Journal of Endocrinology 135 103-114.

Pavelock K, Braas K, Ouafik L, Osol G \& May V 2001 Differential expression and regulation of the vascular endothelial growth factor receptors neuropilin-1 and neuropilin-2 in rat uterus. Endocrinology 142 613-622.

Shimizu T, Jiang JY, Sasada H \& Sato E 2002 Changes of messenger RNA expression of angiogenic factors and related receptors during follicular development in gilts. Biology of Reproduction $\mathbf{6 7}$ $1846-1852$.

Shimizu T, Jiang JY, lijima K, Miyabayashi K, Ogawa Y, Sasada H \& Sato E 2003 Induction of follicular development by direct single injection of vascular endothelial growth factor gene fragments into the ovary of miniature gilts. Biology of Reproduction 69 1388-1393.

Soker S, Takashima S, Miao HQ, Neufeld G \& Klagsbrun M 1998 Neuropilin-1 is expressed by endothelial and tumor cells as an isoform specific receptor for vascular endothelial growth factor. Cell $92735-745$.

Voge JL, Santiago CA, Aad PY, Goad DW, Malayer JR \& Spicer LJ 2004 Quantification of insulin-like growth factor binding protein mRNA using real-time PCR in bovine granulosa and theca cells: effect of estradiol, insulin, and gonadotropins. Domestic Animal Endocrinology 26 241-258.

Wijayagunawardane MP, Miyamoto A, Cerbito WA, Acosta TJ, Takagi M \& Sato K 1998 Local distributions of oviductal estradiol, progesterone, prostaglandins, oxytocin and endothelin-1 in the cyclic cow. Theriogenology 49 607-618.

Xu F, Hazzard TM, Evans A, Charnock-Jones S, Smith S \& Stouffer RL 2005 Intraovarian actions of anti-angiogenic agents disrupt periovulatory events during the menstrual cycle in monkeys. Contraception 71 239-248.

Received 24 August 2005

First decision 11 October 2005

Revised manuscript received 24 November 2005

Accepted 14 December 2005 